\title{
Projected impacts of climate change and ocean acidification on the global biogeography of planktonic Foraminifera
}

\author{
T. Roy ${ }^{1}$, F. Lombard ${ }^{2}$, L. Bopp ${ }^{3}$, and M. Gehlen ${ }^{3}$ \\ ${ }^{1}$ LOCEAN-IPSL, CNRS/IRD/MNHN, Université Pierre et Marie Curie, Case 100, 4 place Jussieu, \\ 75252 Paris CEDEX 5, France \\ ${ }^{2}$ Laboratoire d'Océanographie de Villefranche-sur-Mer, Observatoire Océanologique de Villefranche sur Mer, \\ UPMC Université Paris 06, UMR7093, Paris, France \\ ${ }^{3}$ LSCE-IPSL, CEA/CNRS/UVSQ, Gif sur Yvette, France \\ Correspondence to: T. Roy (tirlod@locean-ipsl.upmc.fr)
}

Received: 22 April 2014 - Published in Biogeosciences Discuss.: 30 June 2014

Revised: 28 November 2014 - Accepted: 18 March 2015 - Published: 19 May 2015

\begin{abstract}
Planktonic Foraminifera are a major contributor to the deep carbonate flux and their microfossil deposits form one of the richest databases for reconstructing paleoenvironments, particularly through changes in their taxonomic and shell composition. Using an empirically based planktonic foraminifer model that incorporates three known major physiological drivers of their biogeography - temperature, food and light - we investigate (i) the global redistribution of planktonic Foraminifera under anthropogenic climate change and (ii) the alteration of the carbonate chemistry of foraminiferal habitat with ocean acidification. The present-day and future (2090-2100) 3-D distributions of Foraminifera are simulated using temperature, plankton biomass and light from an Earth system model forced with a historical and a future (IPCC A2) high $\mathrm{CO}_{2}$ emission scenario. Foraminiferal abundance and diversity are projected to decrease in the tropics and subpolar regions and increase in the subtropics and around the poles. Temperature is the dominant control on the future change in the biogeography of Foraminifera. Yet food availability acts to either reinforce or counteract the temperature-driven changes. In the tropics and subtropics the largely temperature-driven shift to depth is enhanced by the increased concentration of phytoplankton at depth. In the higher latitudes the food-driven response partly offsets the temperature-driven reduction both in the subsurface and across large geographical regions. The large-scale rearrangements in foraminiferal abundance and the reduction in the carbonate ion concentrations in the habitat range of planktonic foraminifers - from $10-30 \mu \mathrm{mol} \mathrm{kg}^{-1}$ in their
\end{abstract}

polar and subpolar habitats to $30-70 \mu \mathrm{mol} \mathrm{kg}^{-1}$ in their subtropical and tropical habitats - would be expected to lead to changes in the marine carbonate flux. High-latitude species are most vulnerable to anthropogenic change: their abundance and available habitat decrease and up to $10 \%$ of the volume of their habitat drops below the calcite saturation horizon.

\section{Introduction}

Large-scale changes to the biogeography and shell chemistry of planktonic Foraminifera have the potential to alter the marine carbonate flux. Planktonic Foraminifera form shells of calcium carbonate (tests). Through the sinking of their tests to the seafloor, planktonic Foraminifera contribute as much as $32-80 \%$ of the global flux of calcium carbonate (Schiebel, 2002), despite their relatively sparse distribution throughout the ocean (Buitenhuis et al., 2013). Thus, they represent one of the three planktonic groups that dominate the oceanic carbonate flux, alongside coccolithophores and pteropods (Honjo, 1996). Indeed, much of the seafloor is covered by foraminiferal tests. This is partly due to the efficient transport of Foraminifera to the ocean floor since they are comparatively large (mostly between 0.01 to $1 \mathrm{~mm}$ ) and have rapid sinking speeds (Berger and Piper, 1972). Also, the tests of Foraminifera are relatively well preserved because they are composed of calcite, the less soluble of the biogenic forms of calcium carbonate. 
Under future scenarios of climate change, ocean acidification is projected to reduce the carbonate production by planktonic calcifiers (Orr et al., 2005). As the ocean absorbs excess atmospheric $\mathrm{CO}_{2}$, the increase in dissolved $\mathrm{CO}_{2}$ results in a reduction in $\mathrm{pH}$ (i.e. an increase in acidity) and a reduction in the concentration of carbonate ions $\left[\mathrm{CO}_{3}^{2-}\right]$. This decrease in carbonate concentration makes it more difficult for calcifying organisms to form biogenic calcium carbonate. It also leads to a reduction in the calcium carbonate saturation state $\left(\Omega_{\mathrm{C}}\right)$ of the oceans (Feely et al., 2004), where $\Omega_{\mathrm{C}}=\frac{\left[\mathrm{Ca}^{2+}\right]\left[\mathrm{CO}_{3}^{2-}\right]}{K_{\mathrm{sp}}^{\mathrm{CaCO}_{2}}}$, $\left[\mathrm{Ca}^{2+}\right]$ and $\left[\mathrm{CO}_{3}^{2-}\right]$ are the calcium and carbonate ion concentrations and $K_{\text {sp }}$ is the stoichiometric solubility product of calcite $\left(\mathrm{CaCO}_{3}\right)$.

Present-day responses of planktonic Foraminifera to anthropogenic change are likely to provide a "living laboratory" for interpreting past responses to climatic change that have been recorded in the sediments over geological timescales. Foraminifera are expected to be useful biological indicators of anthropogenic climate change in the marine environment because

- Foraminifera are established proxies of past climatic conditions (Kucera et al., 2005) and, by corollary, are expected to "record" future climate change,

- the present-day global distribution of Foraminifera is one of the best known of all oceanic taxa (Rutherford et al., 1999) and can provide a useful baseline for measuring change,

- there are no known specific predators of Foraminifera (Hemleben et al., 1989) so changes in the distributions of Foraminifera are more likely to reflect climatic rather than ecological changes,

- the spatial distributions of pelagic organisms are expected to shift faster in response to climate change than those in demersal species (Pereira et al., 2010),

- the growth rates and abundances of Foraminifera are very responsive to changes in temperature, particularly at the limit of their temperature range (Rutherford et al., 1999),

- historical changes in foraminiferal abundance have been shown to reflect anthropogenic climate change (Field et al., 2006), and

- changes in the abundance and distribution of Foraminifera are well preserved in ocean sediments, and can be measured from plankton tows and sediment traps.

Temperature, food availability and light traits demarcate much of the foraminiferal distribution throughout the global ocean (Hemleben et al., 1989). Temperature exerts a firstorder control on the distribution of Foraminifera (Rutherford et al., 1999). Each species has a unique optimum temperature range with a fairly sharp drop in their growth rates at either extreme (Lombard et al., 2009a; Fig. S1). Yet other factors have been shown to influence the distribution patterns of Foraminifera (e.g. Fairbanks et al., 1982; Bijma et al., 1990, 1992). Light also plays an important role in the distribution of many Foraminifera species, both directly through providing energy to the algal symbionts hosted by some species of Foraminifera (Spero and Lea, 1993) and indirectly by controlling the distribution of the foraminiferal prey (Bijma et al., 1992). There are some generalizations that can be made about the broadscale biogeography of Foraminifera based on light availability. Planktonic Foraminifera can be divided into to two groups based on whether or not their tests carry spines (spinose) or not (non-spinose). Many of the spinose species host algal symbionts that can contribute to the growth of the Foraminifera. Species with algal symbionts are generally optimized for shallow, high-light, low-nutrient environments, so dominate the abundance in the oligotrophic gyres. Some symbiont-barren species, such as Globigerina bulloides and Neogloboquadrina pachyderma, are optimized for survival in regions with high productivity. Prey availability has also been shown to have a significant impact on the distribution of Foraminifera (Ortiz et al., 1995; Watkins et al., 1996, 1998). The spinose species have calcareous spines that assist in prey capture and tend to be carnivorous or omnivorous, feeding on copepods and other zooplankton, while the non-spinose species tend to prefer phytoplankton (Spindler et al., 1984).

Given the sensitivity of planktonic Foraminifera to environmental change and their contribution to the global carbonate flux, it is timely to address how the planktonic Foraminifera could respond to anthropogenic perturbations in the oceanic environment. Changes in the characteristics of planktonic foraminiferal assemblages preserved in microfossil-rich sediments and knowledge of the ecophysiological traits of Foraminifera species have helped to reconstruct past environmental conditions to as far back as 120 million years ago. Here, we reverse the problem and project the future change by the end of the century in both (i) the 3-D biogeography of planktonic Foraminifera based on their physiological sensitivities to environmental conditions (temperature, food and light) and (ii) the carbon chemistry of their habitat with ocean acidification.

\section{Materials and methods}

\subsection{Earth system model and simulations}

To simulate the present-day and future global ocean environments, we used the Institut Pierre-Simon Laplace Coupled Model 4 (IPSL-CM4) model. The IPSL model couples the Laboratoire de Météorologie Dynamique atmospheric model (LMDZ-4), with a horizontal resolution of about $3 \times 2.5^{\circ}$ and 19 vertical levels (Hourdin et al., 2006), to the OPA-8 (Océan 
PArallélisé version 8) ocean model, with a horizontal resolution of $2^{\circ} \times 2^{\circ} \cdot \cos \varphi, 31$ vertical levels and a surface ocean thickness of $10 \mathrm{~m}$, and the LIM (Louvain-la-Neuve Sea Ice Model) sea-ice model (Madec et al., 1998). The terrestrial biosphere is represented by the global vegetation model ORCHIDEE (Organising Carbon and Hydrology In Dynamic Ecosystems Environment; Krinner et al., 2005) and the marine biogeochemical cycles by the PISCES (Pelagic Interaction Scheme for Carbon and Ecosystem Studies) model (Aumont et al., 2003).

PISCES simulates the cycling of carbon, oxygen and the major nutrients determining phytoplankton growth $\left(\mathrm{PO}_{4}^{3-}\right.$, $\mathrm{NO}_{3}^{-}, \mathrm{NH}_{4}^{+}, \mathrm{Si}, \mathrm{Fe}$ ). Phytoplankton growth is limited by the availability of external nutrients, as well as temperature and light. The model has two phytoplankton size classes (small and large), representing nanophytoplankton and diatoms, as well as two zooplankton size classes (small and large), representing microzooplankton and mesozooplankton. The $\mathrm{C}: \mathrm{N}: \mathrm{P}$ ratios are assumed to be constant at $122: 16: 1$ (Anderson and Sarmiento, 1994), while the internal ratios of $\mathrm{Fe}: \mathrm{C}, \mathrm{Chl}: \mathrm{C}$ and $\mathrm{Si}: \mathrm{C}$ of phytoplankton are predicted by the model. For more details on PISCES, see Aumont and Bopp (2006) and Gehlen et al. (2006).

To produce the simulations used here, the IPSL model is forced with historical (1860-1999) $\mathrm{CO}_{2}$ emissions (Marland and Andres, 2005) and the IPCC AR4 (Fourth Assessment Report) A2 high $\mathrm{CO}_{2}$ emission future (2000-2100) scenario (Nakicenovic et al., 2000). To calculate the input fields for the FORAMCLIM model (i.e. ocean temperature, $T$; total phytoplankton concentration, PHY; photosynthetically active radiation, PAR; and the carbonate ion concentration, $\mathrm{CO}_{3}^{2-}$ ), a monthly climatology is calculated by averaging the drift-corrected fields over two 10-year periods: present (2000-2009) and future (2090-2099). These IPSL model simulations have been evaluated over the historical period (Schneider et al., 2008) and have contributed to multimodel studies of the future change in marine primary productivity (Steinacher et al., 2010) and the carbon cycle (Roy et al., 2011).

\subsection{Foraminifera model (FORAMCLIM)}

We use the FORAMCLIM model (Lombard et al., 2011) to simulate the growth rates and the abundances of eight common and widely studied foraminiferal species. Five of the simulated species are spinose (Orbulina universa, Globigerinoides sacculifer, Globigerinoides ruber, Globigerinella siphonifera, Globigerina bulloides) and three species are nonspinose (Neogloboquadrina dutertrei, Neogloboquadrina incompta, Neogloboquadrina pachyderma). The FORAMCLIM model incorporates (i) the response of each species of Foraminifera to multiple environmental drivers (food, temperature and light) and (ii) the impact of these drivers on independent process (photosynthesis, nutrition and respiration). Growth rates in the model are the result of the antago- nism between food inputs (nutrition, photosynthesis) and the physiological expenses of the organisms (respiration). For a full appreciation of the model design, readers are encouraged to refer to the model description in Lombard et al. (2011) and references therein.

The growth-rate relationships in FORAMCLIM were based on the observed physiological responses of living specimens under controlled laboratory conditions (Lombard et al., 2009a, b, 2011). In FORAMCLIM, the daily growth rate $\mu\left(\mathrm{d}^{-1}\right)$ is calculated as $\operatorname{In}\left(W_{\mathrm{f}} / W_{\mathrm{i}}\right)$, where $W_{\mathrm{f}}$ and $W_{\mathrm{i}}$ are the final and initial weights of the Foraminifera over a 1-day period. The change in weight, $\Delta W,\left(\mu \mathrm{gC} \mathrm{d}^{-1}\right)-$ that is, the species-specific change in weight of a $250 \mu \mathrm{m}$ individual per day - is simulated based on three main physiological rates: nutrition $(N)$, respiration $(R)$ and photosynthesis by the algal symbionts $(P)$.

$$
\Delta W(T, F, \mathrm{PAR})=N(T, F)+P(T, \mathrm{PAR})-R(T)
$$

These physiological rates are a function of ocean temperature $(T)$, light (PAR, photosynthetically active radiation) and food concentration $(F)$. Here, the total phytoplankton concentration (PHY) is used as a proxy for $F$, according to Lombard et al. (2011). We use the 3-D decadal-mean climatologies of $T, F$ and PAR for present and future time slices of the IPSL model simulations.

The relationships between growth rates and abundances were calibrated against abundances observed in multinet plankton tows (Lombard et al., 2011). Based on the strong relationship between physiological rates and abundances observed in multinet plankton tows, an exponential relationship between abundance (Abund, individuals per $\mathrm{m}^{3}$ ) and $\mu$ was assumed (Lombard et al., 2011), where

Abund $=a \mu^{b}-a+0.1$.

Generally, the abundance, or standing stock in the water column, is given by the annual mean: $\sum_{t=1: 12} \frac{\operatorname{Abund}_{i}(t)}{12} \mathrm{~d} t$. In the cases where we estimate the maximum abundance that could potentially reach the ocean sediments, the monthly-mean depth-integrated abundances are integrated over the seasonal cycle: $\sum_{t=1: 12} \operatorname{Abund}_{i}(t) \mathrm{d} t$. The relative abundances, Rabund, for each species are as follows: $\operatorname{Rabund}_{i}=\frac{\text { Abund }_{i}}{\sum_{i=1: 8} \text { Abund }_{i}} \times$ $100 \%$.

All the physiological parameters are species-specific. The most relevant parameters to this study are listed in Table 1. The contribution of photosynthetically derived organic matter to the nutrition rate is set by both ${ }^{\%} p$, the fraction of the symbiont photosynthesis that is utilized in foraminiferal growth, and $s_{\mathrm{nb}}$, the number of algal symbionts per $250 \mu \mathrm{m}$ individual (Table 1). Photosynthesis only contributes to the growth rate in species that bear algal symbionts. The fooddriven component of the foraminiferal nutrition rate is largely dependent on the half-saturation constant for the MichaelisMenten relationship, $k_{\mathrm{n}}$. Species with lower $k_{\mathrm{n}}$ tend to be 
Table 1. Key species-specific parameters used in the FORAMCLIM model. The half-saturation constant for the Michaelis-Menten relationship that describes the influence of food availability on the nutrition rate, $k_{\mathrm{n}}$; the fraction of the symbiont photosynthesis that is utilized in foraminiferal growth, ${ }^{\%} p$; and the number of symbionts per individual $250 \mu \mathrm{m}$ foraminifer, $s_{\mathrm{nb}}$.

\begin{tabular}{lrrr}
\hline & $k_{\mathrm{n}}\left(\mu \mathrm{gC} \mathrm{L}{ }^{-1}\right)$ & ${ }^{\%} p$ & $s_{\mathrm{nb}}$ \\
\hline O. universa & 1.73 & 0.46 & 716 \\
G. sacculifer & 1.32 & 0.40 & 1160 \\
G. siphonifera & 1.19 & 0.30 & 720 \\
G. ruber & 0.51 & 0.37 & 1104 \\
N. dutertrei & 1.00 & - & - \\
G. bulloides & 6.84 & - & - \\
N. incompta & 3.33 & - & - \\
N. pachyderma & 4.70 & - & - \\
\hline
\end{tabular}

more adapted to oligotrophic waters, while species with high $k_{\mathrm{n}}$ tend to require higher food concentrations for growth.

\subsection{Foraminiferal assemblage and calcite saturation data}

For model evaluation we use two independent data sets: (i) the surface abundances from global plankton tows (Bé and Tolderlund, 1971) and (ii) the relative abundances from sediment top cores. The observed relative abundances of Foraminifera in sediment cores (Fig. S2a in the Supplement) are compiled from the MARGO (Multiproxy Approach for the Reconstruction of the Glacial Ocean surface) database (Barrows and Juggins, 2005; Hayes et al., 2005; Kucera et al., 2004). Although the key focus of the MARGO database is the reconstruction of sea surface temperatures, the relative abundances are also available. We compiled all the available relative abundances in the MARGO database from the top cores and recalculated the relative abundances based on only the eight species used in this study.

The empirical relationships between foraminiferal growth rates and abundances in the FORAMCLIM model were originally calibrated against a compilation of multinet plankton tow data (Watkins et al., 1996, 1998; Schiebel et al., 2001, 2004; Field, 2004; Kuroyanagi and Kawahata, 2004), which is why we cannot use this database to evaluate the model. We use the sampling sites from this same data set to characterize the carbonate chemistry of the present-day potential habitat of foraminiferal species. Here we "sample" the observed calcite saturation state, $\Omega_{\mathrm{C}}$, at the same locations (latitude, longitude, depth; Fig. S2b) where Foraminifera have been collected in multinet plankton tows (Field, 2004; Kuroyanagi and Kawahata, 2004). $\Omega_{\mathrm{C}}$ is calculated based on the GLODAP (Global Ocean Data Analysis Project) (Key et al., 2004) and WOCE (World Ocean Circulation Experiment) databases. For each species of Foraminifera we estimate the percentage of the abundance residing in waters of different $\Omega_{\mathrm{C}}$ ranges.

\subsection{Model performance}

The FORAMCLIM model captures the broadscale patterns of abundance and species dominance. The distributions of surface abundance from plankton tows (Bé and Tolderlund, 1971) are well captured by the model, with the highest abundances in the tropics and subpolar regions and the lowest in the subtropics (Fig. S3a). However, surface abundances tend to be overestimated, particularly in the subtropics. This is most likely due to the model being calibrated against multinet plankton tow data, which uses smaller mesh sizes $(63-100 \mu \mathrm{m})$ relative to the $200 \mu \mathrm{m}$ used by Bé and Tolderlund (1971).

Qualitatively, the dominant species (the species with the highest abundance) were also simulated well by the model with $G$. bulloides in the more productive upwelling areas and temperate zones, G. ruber in the subtropical gyres, $N$. pachyderma in the subpolar and polar regions and G. sacculifer dominating in the tropical and subtropical regions in between (Fig. S3). The model reproduced $43 \%$ of the observed species dominance from surface plankton tow data (Table 2). This level of agreement is lower than the modelbased and satellite-based estimates of Lombard et al. (2011) (Table 2) and is most likely due to the displacement of the simulated water masses and oceanic fronts relative to their real-world counterparts, as is typical of Earth system models (Seferian et al., 2013). Also, some species have quite similar abundances locally, so small errors in abundance can lead to significant errors in species dominance.

The relative abundances and diversity are well captured by the model, with the relative abundance root mean square errors (RMSE) ranging between 3.2 and $24.1 \%$ and with a diversity RMSE of 0.48 (Table 2). For all species, expect $N$. pachyderma, the relative abundance RMSEs are slightly larger than in Lombard et al. (2011) but smaller than in Fraile et al. (2008).

In summary, there is a tendency to slightly overestimate the standing stock of Foraminifera relative to the sparse surface plankton data and to underestimate the changes in abundance in response to changing environmental conditions relative to observed abundances from sediment cores (Kageyama et al., 2012).

\subsection{Modelling planktonic Foraminifera: strengths and limitations}

The two most established approaches currently used to simulate the biodiversity of Foraminifera are the ecophysiological approach used in this study, FORAMCLIM (Lombard et al., 2011), and the ecosystem approach developed specifically to capture dynamic changes in planktonic foraminiferal populations, PLAFOM (Fraile et al., 2008). All approaches 
Table 2. Assessment of the simulated distribution of foraminiferal species (percentage of area with model-data agreement) using the plankton tow data of Bé and Tolderlund (1971). The RMSE of diversity and relative abundance are assessed against the MARGO top-core data. Lombard $^{1}$ is the model-based (FORAMCLIM) estimate from Lombard et al. (2010); Lombard ${ }^{2}$ refers to the satellite-based estimate from Lombard et al. (2010); Fraile 1 refers to the model-based (PLAFOM) estimate from Fraile et al. (2008).

\begin{tabular}{|c|c|c|c|c|}
\hline & \multirow[t]{2}{*}{ This study } & \multicolumn{3}{|c|}{ Other studies } \\
\hline & & Lombard $^{1}$ & Lombard $^{2}$ & Fraile $^{1}$ \\
\hline Dominant species (\%) & $43 \%$ & $59 \%$ & $71 \%$ & \\
\hline Diversity (RMSE) & 0.56 & 0.48 & 0.52 & \\
\hline \multicolumn{5}{|c|}{ Relative abundance (RMSE) } \\
\hline O. universa & 3.2 & 3.24 & 3.28 & - \\
\hline G. sacculifer & 12.1 & 12.38 & 17.46 & 23 \\
\hline G. siphonifera & 6.1 & 5.29 & 6.00 & - \\
\hline G. ruber & 24.1 & 23.14 & 17.76 & 25 \\
\hline N. dutertrei & 18.3 & 17.53 & 17.23 & - \\
\hline G. bulloides & 22.0 & 21.02 & 18.97 & 25 \\
\hline N. incompta & 16.2 & 15.85 & 14.85 & 22 \\
\hline N. pachyderma & 20.6 & 17.01 & 12.32 & 9 \\
\hline
\end{tabular}

used for projecting climate impacts on marine biogeography have their unique set of strengths and weaknesses (Pereira et al., 2010). One of the drawbacks of the dynamic ecosystem approach is that many processes (i.e. mortality, competition and predation) are not well known (Hemleben et al., 1989). Furthermore, the parameters that describe these processes cannot be optimized independently using the data that is currently available. Another limitation of the Fraile et al. (2008) approach is that the depth profiles of foraminiferal abundance are not simulated. Capturing vertical changes is important if we want to estimate the impact of shifts in habitat preference on both the net foraminiferal abundance and the climate signals recorded by foraminiferal paleoproxies. However, the dynamical approach could be better adapted to simulate events controlled by population biology and hydrodynamics, which are known to be important in controlling Foraminifera abundance and their flux to the deep ocean (De La Rocha and Passow, 2007); these include the pulsed fluxes of foraminiferal tests that can occur sporadically (Sautter and Thunell, 1991) or in short bursts in response to storms (Schiebel et al., 1995) and the advection of empty tests from their production sites (Siegel and Deuser, 1997; von Gyldenfeldt et al., 2002).

One of the attractive aspects of the FORAMCLIM model is that it is empirically based. The relationships between environmental conditions (i.e. light, temperature) and foraminiferal growth rates are derived under controlled laboratory conditions. Since it is impossible, based on the available knowledge, to incorporate the influence of all ecological and physiological processes on foraminiferal abundance, the relationships between growth rates and abundance are calibrated against the standing stock of Foraminifera from multinet plankton tows, effectively allowing us to bridge this sizeable knowledge gap. The parameters of this calibration inte- grate the influence of the processes unresolved by the model. By applying the Foraminifera model to climate simulations, we can project these observation-based relationships into the future.

Critical to reliable model performance is that these model relationships are realistic. Here we elaborate on a previous discussion of the strengths and limitations of the FORAMCLIM model (Lombard et al., 2011). First, the laboratorybased growth rate relationships may not hold for the real ocean. The laboratory experiments were conducted on specific specimens whose response to environmental perturbations may not be representative of the global population similar to the responses that have been observed for different strains of coccolithophore species in response to changes in carbonate concentration (Ridgwell et al., 2009; Langer et al., 2009). Also, Foraminifera in the laboratory could be more sensitive to perturbations in environmental conditions than in their natural habitat. It has not been possible to reproduce planktonic Foraminifera in the laboratory, which is one indication that Foraminifera in the laboratory are not behaving as they would in their natural environment. Furthermore, the physiological responses of Foraminifera in the laboratory could be more related to stress than to environmental perturbations. It is important to keep in mind that although all physiological laboratory experiments are artificial, they are currently the most direct approach available for quantifying the growth response of Foraminifera to specific environmental changes.

Another potential weakness is that the relationships between the abundances and the growth rates are weakly correlated (Lombard et al., 2011). This could partly be due to each morphological species being a combination of cryptic species, each with distinct habitat preferences and responses to environmental change (de Vargas et al., 2002). 

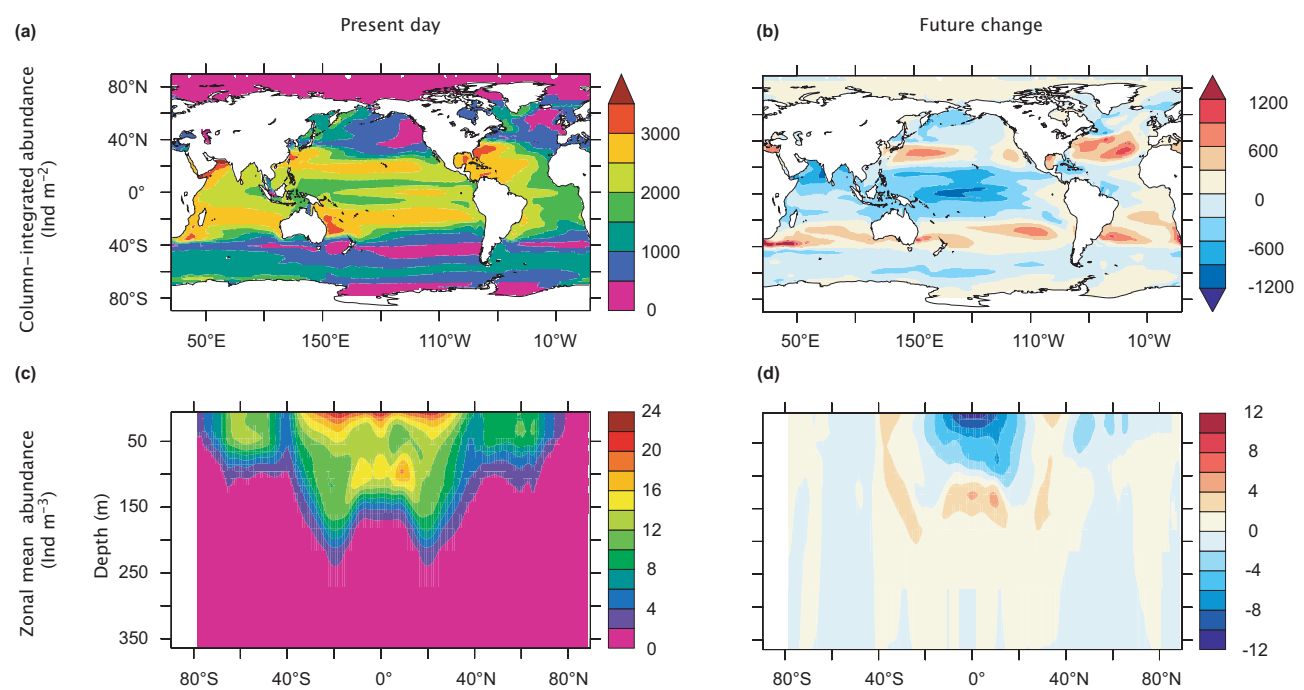

(d)

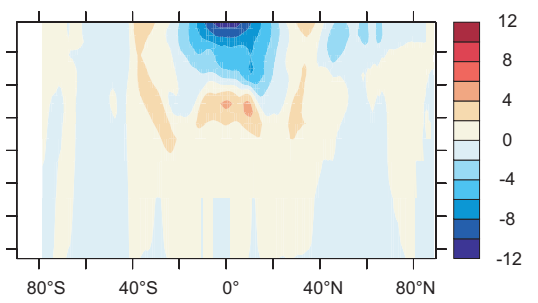

Figure 1. Present $(\mathbf{a}, \mathbf{c})$ and future changes $(\mathbf{b}, \mathbf{d})$ in the total simulated abundance (all species). (A, c) column-integrated abundance (ind $\mathrm{m}^{-2}$ ) and $(\mathbf{b}, \mathbf{d})$ zonal-mean abundance $\left(\right.$ ind $\left.^{-3}\right)$.

A convincing explanation for the weak relationship between biomass and abundance could be related to the FORAMCLIM model not resolving variations in shell size: a wide range of abundances can be fitted to the same total biomass of a foraminiferal population depending on how this biomass is distributed over different size classes. To illustrate this point, we can take the typical biomass size spectrum from Schiebel and Mollevan (2012): $1 \mathrm{~m}^{3}$ of water with a foraminiferal abundance of 100 individuals $\mathrm{m}^{-3}$, which are grouped into three size classes of 100-150, 150-250 and $250+\mu \mathrm{m}$, with each size class having 75, 19 and 6 individuals respectively. A small change in the size spectrum (e.g. having just two more individuals in the largest and intermediate size classes (i.e. 21 and 8 individuals respectively) would require a large decrease in the total abundance from 100 to 68 individuals to match the same total biomass.

Another limitation of the FORAMCLIM model is that it currently includes only the species on which sufficient physiological laboratory experiments have been conducted, that is, 8 of the approximately 50 species of morphologically distinct planktonic Foraminifera. Therefore, it cannot be used to estimate the total (i.e. all-species) foraminiferal abundance, diversity or carbonate production. Nevertheless, based on sediment top-core samples (Kucera et al., 2004), the eight species currently represented in the FORAMCLIM model account for a large proportion of the total abundance (about 50\%).

\section{Results}

\subsection{Future changes in abundance and diversity}

Under climate change, temperature, food availability and light were perturbed such that the total foraminiferal abun- dance (combined abundance of the eight species in the FORAMCLIM model, Fig. 1a) shifted polewards from the tropics to the subtropics, while abundance decreased in the subpolar regions (Fig. 1b) by the end of the century. The simulated depth-integrated abundance reduced by up to $40 \%$ in the tropics and subpolar regions and increased by greater than $100 \%$ in the subtropics. Throughout the tropics the total abundance (Fig. 1c) shifted deeper in the water column (Fig. 1d), reducing the total abundance of Foraminifera at the ocean surface by more than $50 \%$ (>10 ind $\mathrm{m}^{-3}$, Fig. $2 \mathrm{~b}$ ). Under climate change the pattern of foraminiferal diversity (Fig. 2c) responded similarly to that of abundance: it decreased in the tropics, increased in the subpolar regions (Fig. 2d) and shifted to depth in the tropics (not shown). The decreased diversity in the tropics is primarily due to the local disappearance of $G$. siphonifera and $N$. dutertrei.

In the simulation, three species dominated the changes in total foraminiferal abundance: the two abundant warm-water species $-G$. ruber and G. sacculifer - drove the reduction in total abundance in the tropics and the increase in the subtropics, while $N$. pachyderma dominated the reduction in the high latitudes and the small increases in abundance around the poles (Fig. 3a and b). In the tropics, the climate-driven reductions in the distribution of $G$. ruber and G. sacculifer were similar in magnitude $\left(5 \mathrm{ind} \mathrm{m}^{-3}\right)$, and each integrated to a more than $100 \mathrm{ind} \mathrm{m}^{-2}$ reduction over the whole water column (Fig. 3b). In the high latitudes, the poleward shift in abundance of $N$. pachyderma reduced the net abundance in surface waters $\left(\sim 4\right.$ ind $\left.\mathrm{m}^{-3}\right)$ and throughout the water column $\left(\sim 200\right.$ ind $\mathrm{m}^{-2}$, not shown).

The changes in relative abundance are also presented, since this is what is measured in sediment cores. In the tropics, despite the large decreases in the abundances of the two dominant species (G. ruber and G. sacculifer), their rela- 
(a)

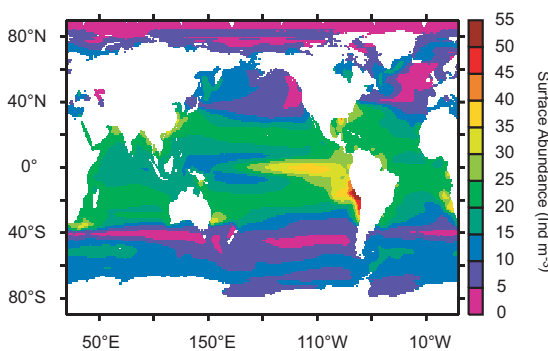

(c)

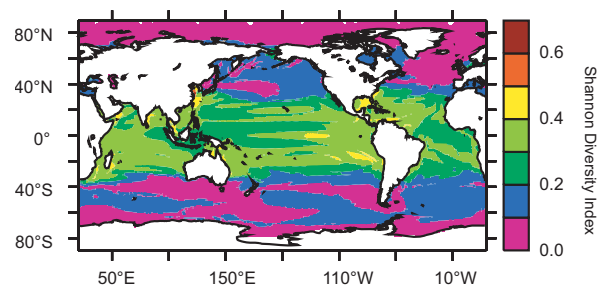

(b)

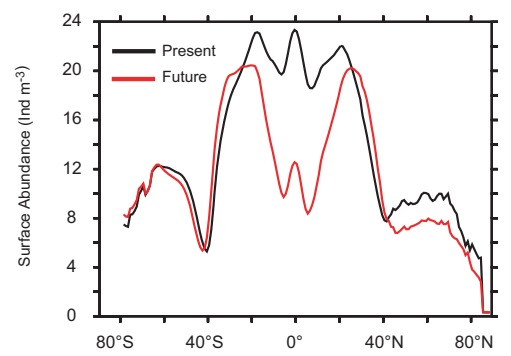

(d)

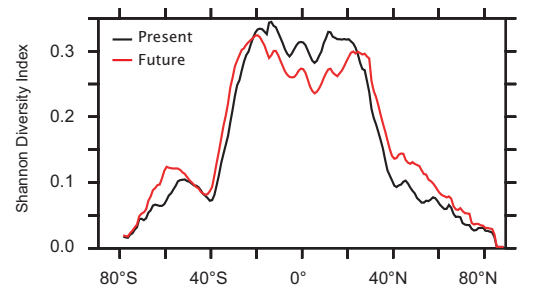

Figure 2. Total surface abundance of Foraminifera (ind $\mathrm{m}^{-3}$ ): (a) present-day surface distribution and (b) zonally averaged surface abundance for the present day and the future. Shannon diversity index of the simulated Foraminifera: (c) surface distribution and (d) zonally averaged for the present day and future.

Surface

(a)

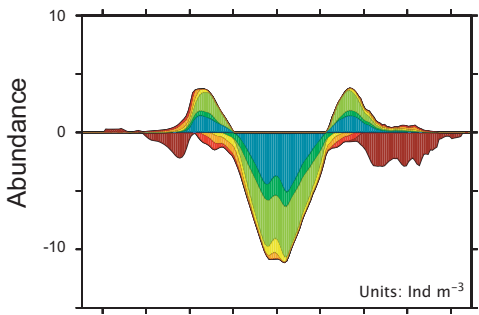

(c)

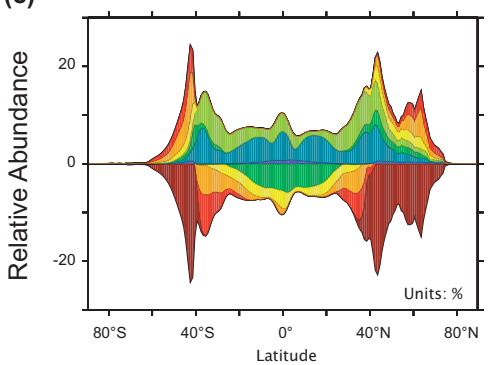

Depth-integrated

(b)

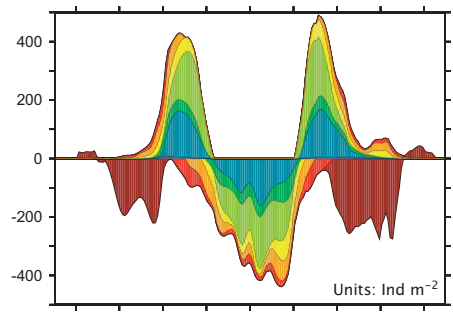

(d)

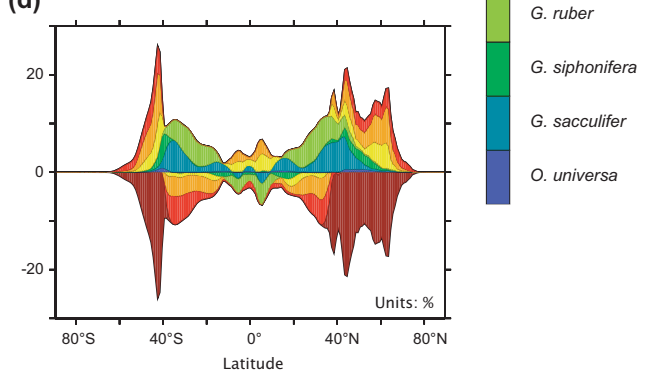

Figure 3. Zonally averaged changes (i.e. future-present) in the abundance and the relative abundance of each foraminifer species simulated in FORAMCLIM $(\mathbf{a}, \mathbf{c})$ at the ocean surface and $(\mathbf{b}, \mathbf{d})$ integrated throughout the water column.

tive abundances at the ocean surface increased (Fig. 3c) and the depth-integrated relative abundances changed very little (Fig. 3d). In the midlatitudes $\left(10-40^{\circ}\right)$, the abundance and relative abundance of $G$. bulloides, $N$. incompta and $N$. dutertrei decreased, while G. sacculifer and G. ruber increased. In the high latitudes $\left(>50^{\circ}\right)$, where the species diver- sity is much lower than in the tropics (Fig. 2c), the changes in abundance resulted in changes in the relative abundance that can interpreted more easily. Although the abundance of G. bulloides, N. incompta and N. dutertrei barely changed (Fig. 3a and b), the large decrease in the abundance of the dominant species, $N$. pachyderma, drove a substantial in- 


\section{Change in foraminifer abundance}
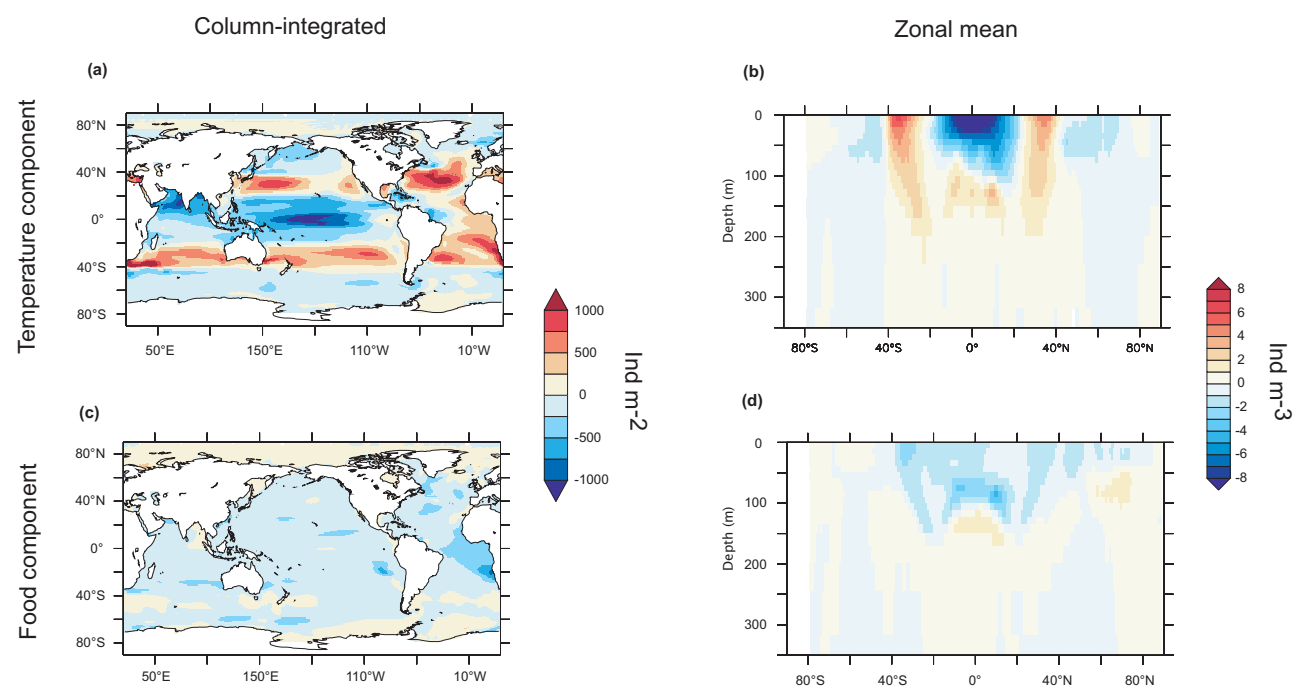

Figure 4. Future changes by 2100 in the dominant environmental drivers of foraminiferal abundance: ocean temperature $\left({ }^{\circ} \mathrm{C}\right)(\mathbf{a})$ at the surface and (b) zonally averaged; phytoplankton concentration $\left(\mu \mathrm{CL}^{-1}\right)(\mathbf{c})$ at the surface and (d) zonally averaged.

crease in the relative abundance of these species (Fig. 3c and d). The more even distribution of abundance between the species resulted in an overall increase in the diversity index in the higher latitudes (Fig. 2d).

\subsection{Environmental drivers of foraminiferal biogeography}

It is not directly possible to separate the impact of temperature and food on foraminiferal distributions in nature, so we turn to the model to attempt to explore the potential relative impacts of projected changes in food, temperature and light on future foraminiferal distributions. An advantage of the FORAMCLIM model is the ease with which the various drivers of the changes in abundance can be disentangled. By systematically allowing only one parameter to vary, we can partially separate the total change in foraminiferal abundance into components driven by each of the environmental drivers - temperature, food and light. Given the paucity of data for the evaluation of these simulated responses, these results should be regarded as initial sensitivity experiments. The future change in ocean temperature (Fig. 4) is the primary driver of the change in the basin-scale biogeography of Foraminifera (Fig. 5), followed by food availability (Figs. 4, 5). Changes in light availability have a minor impact (not shown).

Temperature was the dominant driver of the poleward shift of foraminiferal abundance from the tropics (Fig. 5a). The $1-3{ }^{\circ} \mathrm{C}$ increase in sea surface temperatures in the tropics and subtropics (Fig. 4a), and throughout the water column (Fig. 4b), decreased the habitat suitability in the tropical waters - the waters became too warm for optimal foraminiferal growth - yet increased the habitat suitability in the subtropics (Fig. 5a) and in the deeper waters of the tropics (Fig. 5b).

In the subpolar and polar regions, where $N$. pachyderma dominates (Fig. 3a, b), the shift in abundance was a combined response to temperature- and food-driven changes in nutrition rates (Fig. 5a and c respectively). The broadscale patterns, the subpolar decrease and polar increase in abundance (Fig. 5a, b) were driven by temperature (Fig. 4a). However, increases in phytoplankton concentration in localized patches, particularly in the Southern Ocean (Fig. 4c), and in subsurface waters (Fig. 4d) drove increases in abundance (Fig. 5c and d). The increase in phytoplankton abundance in the Southern Ocean is a shared feature of many future climate change simulations and is explained by the alleviation of light and iron limitation on phytoplankton growth (Steinacher et al., 2010). The food-driven increases in the foraminiferal abundance tended to offset the temperaturedriven reductions. Other areas with similar offsets include large patches throughout the North Atlantic and the equatorial and coastal upwelling regions.

\subsection{Species abundance and potentially suitable habitat}

To assess the species-specific vulnerability of Foraminifera to climate change we calculated the percent change in the globally averaged species abundance and potentially suitable habitat (Fig. 6), where the potential habitat is defined as anywhere where the environmental conditions (i.e. temperature, food and light conditions) are sufficient for foraminiferal growth. Some species "profited" (O. universa, G. sacculifer, G. siphonifera and G. ruber); that is, their potential habitat increased by between 5 and $20 \%$. Whilst higher-latitude 
Surface

(a)

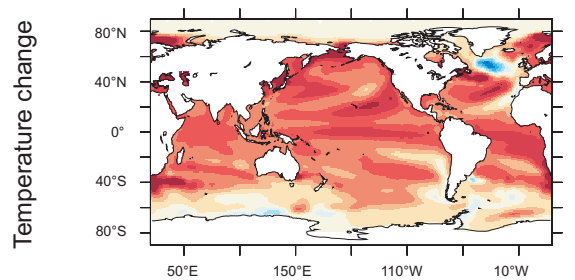

(c)

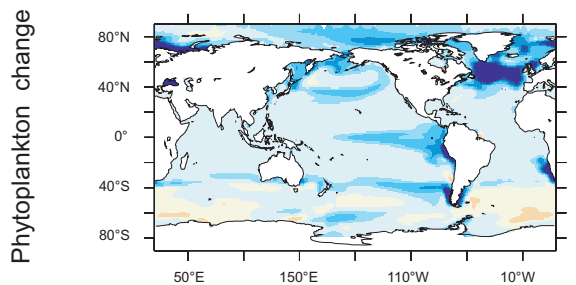

Zonal average

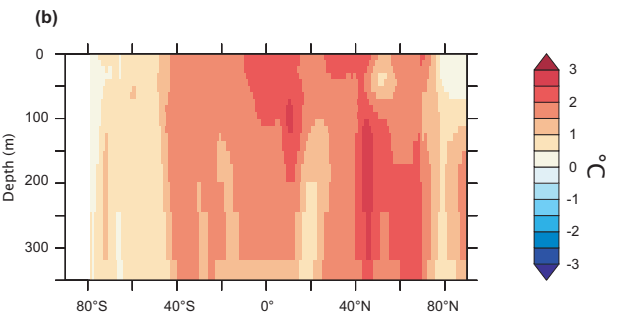

(d)

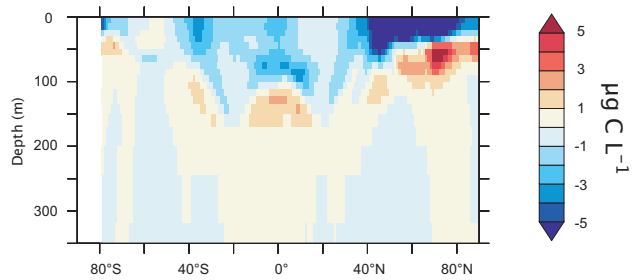

Figure 5. Components of the future change by 2100 in total foraminiferal abundance due to temperature: (a) depth-integrated (ind $\mathrm{m}^{-2}$ ), $(\mathbf{b})$ zonally averaged (ind $\mathrm{m}^{-3}$ ). Components of the future change in total foraminiferal abundance due to food availability: (c) depth-integrated (ind $\mathrm{m}^{-2}$ ), (d) zonally averaged (ind $\mathrm{m}^{-3}$ ).

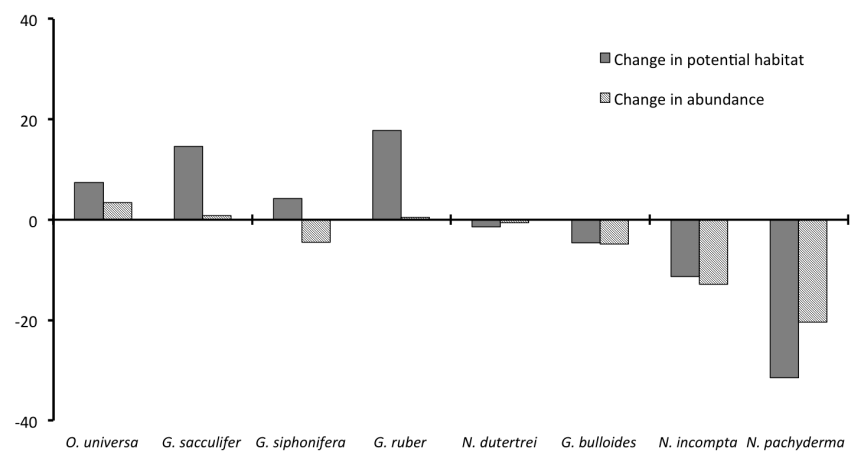

Figure 6. Future change (\%) in the potential habitat range (blue) and abundance (red) of each foraminiferal species. Potential habitat range is defined as the area where a foraminifer has the potential to grow given the environmental conditions (i.e. temperature, food availability and light).

species were more vulnerable (e.g. N. incompta, N. pachyderma), their potential habitat and net abundance decreased by between 10 and $40 \%$. For G. siphonifera the potential habitat increased but the abundance decreased.

\subsection{Carbon chemistry of the foraminiferal habitat}

Although we do not explicitly account for the impact of ocean acidification on either foraminiferal calcification or physiological processes in the current version of the FORAMCLIM model, we can make an assessment of the potential impacts by quantifying the predicted changes in the carbonate concentration, $\left[\mathrm{CO}_{3}\right]^{2-}$, and calcite satura- tion state, $\Omega_{\mathrm{C}}$, within the habitat range of each species of Foraminifera.

First, we would like to have an indication of the presentday distribution of foraminiferal abundance within waters of different $\Omega_{\mathrm{C}}$ classes. We find that only a very small proportion of the abundance of all the foraminiferal species resides in waters with $\Omega_{\mathrm{C}}$ less than 2 , even though substantial volumes of water with low $\Omega_{\mathrm{C}}$ are sampled, particularly in the northern high latitudes (Fig. 7). The highest foraminiferal abundances from the multinet plankton tows were sampled in waters with $3<\Omega_{\mathrm{C}}<6$.

Second, we project how the carbonate chemistry of foraminiferal habitat will change by the end of this century. Calcite saturation states decrease throughout the global ocean and waters with low saturations states $\left(\Omega_{\mathrm{C}}<2\right)$ shoal (Fig. 8a, b) and become more widespread across the surface ocean. Most surface waters polewards of $40^{\circ}$ have $\Omega_{C}<2$. Virtually none of the simulated present-day foraminiferal habitat has ambient $\Omega_{\mathrm{C}}<2$. However, by the end of the century between 10 and $95 \%$ of the habitats of most foraminiferal species have $\Omega_{\mathrm{C}}<2$ (Fig. 8c). High-latitude species, $N$. pachyderma and $N$. incompta, are potentially most vulnerable, with some of their suitable habitat even becoming undersaturated $\left(\Omega_{\mathrm{C}}<1\right)$ with respect to calcite by the end of the century (when $\Omega_{\mathrm{C}}$ is below the threshold of $\Omega_{\mathrm{C}}=1$, mineral calcite becomes unstable). Also, the carbonate ion concentrations of the potential foraminiferal habitat decrease to between 20 and $70 \mu \mathrm{mol} \mathrm{kg}{ }^{-1}$, with the largest reductions in the equatorial regions (Fig. 8d). 


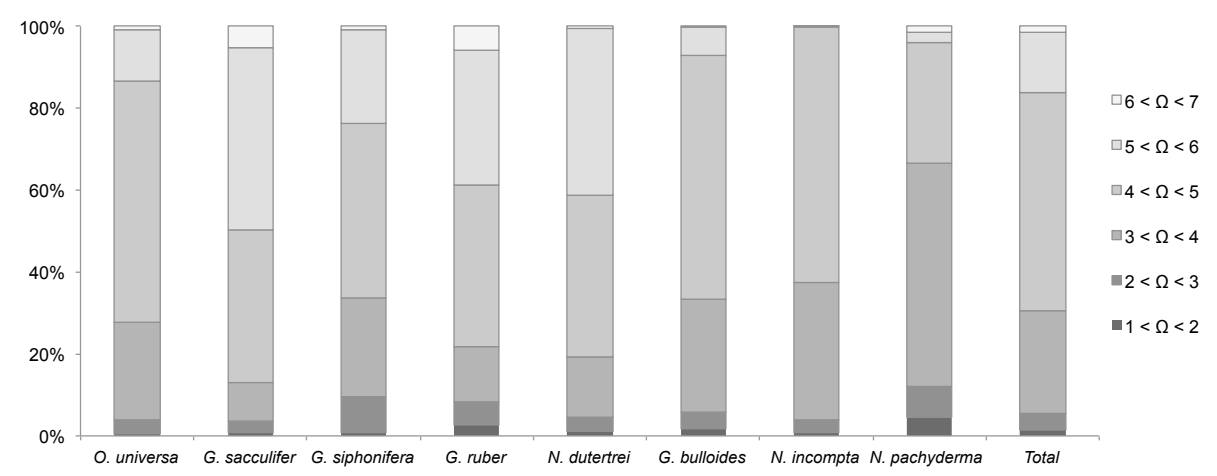

Figure 7. Percentage of the foraminiferal species abundance, collected with multinet plankton tows, that resides in each $\Omega_{\mathrm{C}}$ class.

(a)

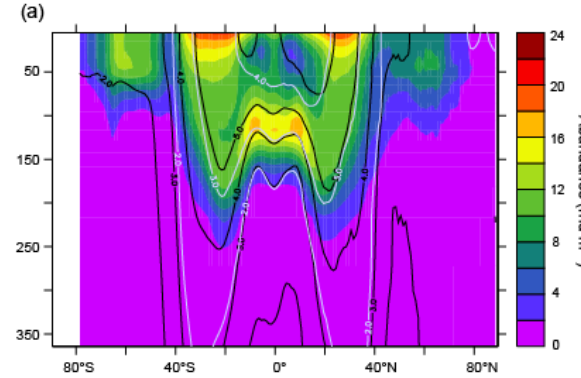

(c)

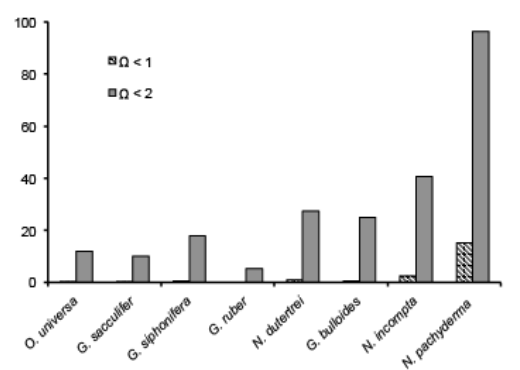

(b)

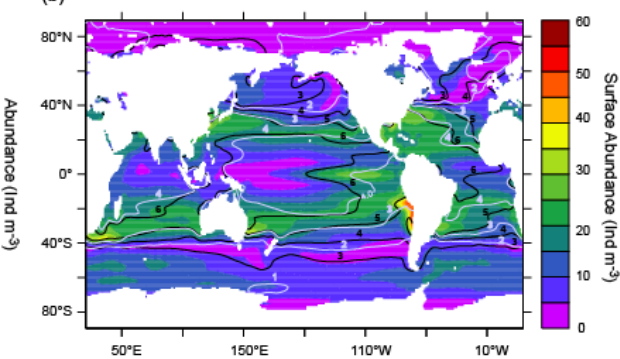

(d)

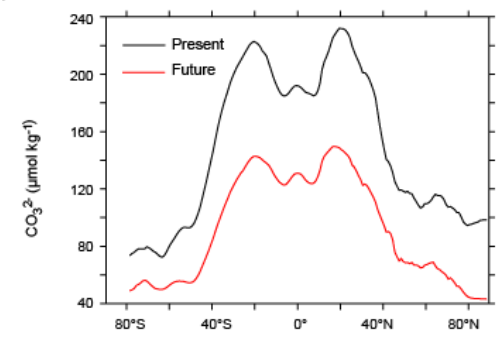

Figure 8. Future changes in carbon chemistry of the potentially suitable habitat of Foraminifera. Simulated present-day total abundance of Foraminifera: (a) zonal mean (ind $\mathrm{m}^{-3}$ ) and (b) surface (ind $\mathrm{m}^{-3}$ ). Contours represent the calcite saturation state, $\Omega_{\mathrm{C}}$, for the present-day (black) and the future (pale blue). For each foraminifer species: (c) the percentage of the future potential habitat with low calcite saturation states, $\Omega_{\mathrm{C}}<2$, and (d) the simulated present and future carbonate ion concentration $\left(\mu \mathrm{mol} \mathrm{kg} \mathrm{kg}^{-1}\right)$ of the potential habitat.

\section{Discussion}

\subsection{Climate impacts}

It is unclear how vulnerable specific foraminiferal species may be to anthropogenic climate change. Since the last substantial extinction event in the Pliocene, the modern assemblage of species has remained relatively stable under glacialinterglacial fluctuations (Jackson and Sheldon, 1994). However, the oceanic environment is fast approaching conditions that are well outside those of glacial-interglacial cycles. It is expected that pelagic species, and in particular planktonic species, will have the potential to escape some climatic changes by shifting their populations to regions with more favourable conditions (Burrows et al., 2011), as predicted here for species such a G. sacculifer and G. ruber. However, we show that the available potential habitat is reduced for high-latitude species, such as $N$. pachyderma, and that this reduction is associated with a drop in the net global abundance. For one species, G. siphonifera, the suitable habitat range increases, yet its net global abundance decreases. Such an increase in habitat range without similar increases in abundance indicates that temperature, light and food availability are perturbed such that the species can exist over a greater habitat range but that the overall environmental conditions are suboptimal for foraminiferal growth.

Based on the FORAMCLIM simulations, it would be expected that anthropogenically driven shifts in the basin-scale biogeography of Foraminifera should be observable (Fig. 3a, b). However, in sediment samples, the changes in the relative 
abundances in some regions, particularly the tropics, may be too small to detect (Fig. 3d). Furthermore, shifts in the species abundance can cause nonintuitive shifts in the relative abundance, particularly in regions of high species diversity such as the tropics. However, in the high latitudes, where the diversity is lower (Fig. 2d), the interpretation of the changes in relative abundance should be simpler.

We have shown that climate change is projected to alter the temperature, food and light conditions that influence foraminiferal growth rates and, consequently, shift both the vertical and geographical distributions of foraminiferal abundance and diversity (Figs. 1 and 2). In the tropics and subtropics, the changes in abundance are driven by the regionally dominant species: G. ruber and G. sacculifer. Here, temperature (Fig. 4) dominates the geographical shifts in foraminiferal abundance, while multiple drivers (phytoplankton and temperature) cause the vertical shifts (Fig. 5). On the contrary, in the polar and subpolar regions food availability and temperature drive the geographical shifts in foraminiferal abundance, while mostly changes in phytoplankton concentrations drive the vertical shifts. The changes in the abundance of Foraminifera are associated with $N$. pachyderma and are in agreement with observational studies (Fairbanks and Wiebe, 1980; Kohfeld et al., 1996; Kuroyanagi and Kawahata, 2004; Bergami et al., 2009) that demonstrate that the geographical distribution was primarily controlled by ocean temperatures, while the vertical distribution was controlled by the depth of the chlorophyll maximum and the pycnocline. Light does not produce a strong change in abundance in our simulations and is therefore not discussed here. In reality, however, the response of symbiont-bearing Foraminifera to light is likely to be much more complex than simulated in the Foraminifera model.

The drivers of vertical and horizontal distributional changes can differ because food, light and temperature may have impacts on foraminiferal abundances that are uncorrelated: they either act to reinforce or counteract each other's impact on foraminiferal abundances. Also, the drivers themselves may not be well correlated. Under climate change, Earth system models simulate increases in ocean temperature in most regions, yet $\mathrm{PP}$ (primary product) can either decrease or increase (Steinacher et al., 2010). Furthermore, the nutritional requirements are unique to each species, representing the different strategies that Foraminifera use to feed and grow. Symbiotic species have a strong dependence on light availability. Therefore, they mostly display horizontal effects and vertical shifts that are restricted to the euphotic zone (up to about $200 \mathrm{~m}$ ). Species without symbionts can display less restricted vertical responses because they do not rely directly on light. They can travel as deep as the food source. Species with a stronger prey dependency are more likely to be more sensitive to changes in the availability of prey than temperature. This complexity is taken into account in the ORCA, PISCES and FORAMCLIM models. For example, in the high latitudes, the dominant species here, N. pachyderma, drives much of the change in the simulated total foraminiferal abundance. Its abundance is reduced throughout most of its habitat range in response to a warming ocean, but its abundance increases over patches of the ocean and shifts to depth in some regions, in response to an increase in food availability. By contrast, in the tropics and subtropics the dominant species G. sacculifer and G. ruber shift polewards and deeper in the water column both as the thermocline and nutricline deepen, yet food availability does not contribute to the latitudinal shifts because the column-integrated food availability is not altered significantly throughout the habitat range.

We show that climate change could result in vertical shifts in foraminiferal abundance that are driven by either food availability or temperature or by both. Interestingly, comparable vertical shifts in foraminiferal abundance over glacialinterglacial time periods may complicate the reconstruction of sea surface temperatures from foraminiferal microfossil deposits: in paleoclimate reconstructions the vertical distributions Foraminifera are generally assumed to be stationary over time (e.g. Kucera et al., 2005).

Opinions differ on the relative impacts of food availability, temperature or other environmental factors on the distribution of planktonic Foraminifera. Although it is generally accepted that at the extremes of a species temperature tolerance, temperature drives the changes in the geographical extent of Foraminifera (Rutherford et al., 1999), each species' preferred temperature range is broad. Within these temperature ranges it has been shown that regional patterns of abundance are strongly correlated with species-specific responses to food, light (Ortiz et al., 1995; Watkins et al., 1996; Field, 2004) salinity and turbidity (Retailleau et al., 2011). By contrast, it could be argued that food availability is generally adequate to maintain foraminiferal populations and that changes in abundance are primarily temperature-driven. A database of time series of abundance and assemblage data and concomitant environmental measurements of temperature, food and light would be an invaluable resource for the evaluation of the drivers of the simulated changes in the distributions of foraminiferal abundance.

The simulated response of foraminiferal diversity to climate change may differ significantly if all extant species could be included in the model. For example, tropical species present in low concentrations, but excluded in this analysis, could flourish as temperatures increase. Also, the vertical stratification of large regions of the global ocean should increase with climate change (Sarmiento et al., 2004), which can increase vertical niche separation, thereby allowing a greater diversity of species to subsist (Al-Saboui et al., 2007). By including more species in the FORAMCLIM model, these effects could counteract the simulated decrease in diversity in the tropics. Another important factor that will influence how diversity responds to climate change is that most foraminiferal morphospecies have many genotypes that exhibit specific ecology, habitat preferences and biogeography (Aurahs et al., 2009). A potential approach to incorporate 
more species diversity, and to partially circumvent the lack of information on key ecological and physiological processes for many foraminiferal species, would be to apply the selfassembling biodiversity approach (Follows et al., 2007) to simulate more complex foraminiferal assemblages.

\subsection{Calcification and acidification impacts}

If net calcification were to scale directly with foraminiferal abundance, the large-scale rearrangements in abundance with climate change would alone cause significant changes in regional carbonate production. For example, in the tropics and subtropics the $40 \%$ decrease in total simulated foraminiferal abundance could produce a $20 \%$ reduction in total planktic foraminiferal carbonate production, given that the eight species in the FORAMCLIM model account for about $50 \%$ of the total planktonic foraminiferal abundance observed in the sediment core tops (Kucera et al., 2004). Such population-driven impacts on carbonate production could be further amplified or dampened if calcification rates themselves are impacted by anthropogenic change. Ocean acidification and the associated decrease in carbonate ion concentrations can alter foraminiferal calcification rates (Lombard et al., 2010; Keul et al., 2013), while higher ocean temperatures could accelerate calcification rates within certain temperature windows.

With future increases in atmospheric $\mathrm{CO}_{2}$, we show that the carbonate concentration of the preferred habitat range of planktonic Foraminifera decreases zonally from $10-30 \mu \mathrm{mol} \mathrm{kg}^{-1}$ in the polar and subpolar regions to 30 $70 \mu \mathrm{mol} \mathrm{kg}^{-1}$ in the subtropical and tropical regions by the end of this century (Fig. 8d). Even without dropping below the calcite saturation state, such changes in carbonate ion concentration may have significant impacts on foraminiferal tests. Evidence exists for shell thinning in Foraminifera over recent (de Moel et al., 2009; Moy et al., 2009) and geological timescales (Barker and Elderfield, 2002), and it has been suggested that these changes are a response to higher atmospheric $\mathrm{CO}_{2}$ concentrations and the reduction of carbonate ion concentrations (Keul et al., 2013). As with other calcifying planktonic species (Riebesell et al., 2000; Zondervan et al., 2001; Fabry et al., 2008; Comeau et al., 2010), calcification by Foraminifera is sensitive to changes in the carbonate ion concentration both in their natural environment (Beer et al., 2010) and in laboratory cultures (Spero et al., 1997; Bijma et al., 1999, 2002; Russell et al., 2004; Beer et al., 2010; Lombard et al., 2010; Manno et al., 2012; Keul et al., 2013).

Despite the uncertainties associated with foraminiferal calcification, it is interesting to have a sense of the magnitude of the change in calcification that could be expected by applying laboratory-derived relationships (i.e. calcification vs. carbonate ion concentration) from the literature to the foraminiferal distributions and the carbonate ion concentrations simulated here. For example, in a series of laboratory experiments, a reduction of $30-40 \mu \mathrm{mol} \mathrm{kg}^{-1}$ in the car- bonate ion concentration was associated with a $21-30 \%$ reduction in the calcification rates of $N$. pachyderma (Manno et al., 2012). The reduction in the carbonate ion concentration throughout the habitat of $N$. pachyderma is projected to be $\sim 30 \mu \mathrm{mol} \mathrm{kg}^{-1}$ (Fig. 8d), and, by crude extrapolation, we could expect a similar $>20 \%$ drop in the net $N$. pachyderma foraminiferal carbonate flux in the high latitudes due to ocean acidification by the end of this century. This reduction would reinforce the reduction in carbonate production due to the net climate-driven decrease in abundance of this species throughout its habitat range (Figs. 3b, 6). Similarly, based on the observed changes in the calcification rates of G. sacculifer with carbonate ion concentration (Bijma et al., 2002; Lombard et al., 2010, see Eq. 3), the projected reduction of up to $70 \mu \mathrm{mol} \mathrm{kg}^{-1}$ in the carbonate ion concentration in the tropical and subtropical habitat range of $G$. sacculifer (Fig. 8d) could result in an up to $10 \%$ reduction in the calcification rates of this species. Again, this would reinforce the reduction in carbonate production associated with the decrease in the abundance of this species throughout the tropics (Fig. 3b), yet it would counteract the increase in carbonate production associated with enhanced abundance in the subtropics.

In the polar and subpolar regions, N. pachyderma dominates the assemblages (Fig. S3b). The tests of $N$. pachyderma are expected to be the most vulnerable to dissolution because the polar regions have lower carbonate ion concentrations and are consequently closer to the threshold of calcite saturation $(\Omega=1)$. We show that by the end of the century, most of the habitat of high-latitude species drops below the calcite saturation state of 2 with more than $10 \%$ of the potential habitat of the dominant high-latitude species, N. pachyderma, residing below the saturation horizon (Fig. 8c); this could result in shell dissolution throughout this range.

Although calcification by Foraminifera is directly influenced by $\mathrm{CO}_{3}^{2-}$, many other environmental factors besides ambient carbonate ion concentrations influence the shell weight (de Villiers, 2004), including temperature (Hemleben et al., 1989; Manno et al., 2012), light (Spero, 1992; Lombard et al., 2010) and growth potential (Aldridge et al., 2012). Clearly, the environmental controls on calcite production by Foraminifera are still poorly understood. A complex intra- and interspecies-specific interplay of factors drive foraminiferal shell weights (Beer et al., 2010). Both the magnitude and the sign of the slope of the relationships between shell weight and carbonate ion concentrations vary between and within a species (Keul et al., 2013), and they vary widely depending on whether the relationships were based on plankton tows (Beer et al., 2010), top-core sediments (Barker and Elderfield, 2002) or laboratory cultures (Bijma et al., 1999, 2002). A quantitative assessment of the impact of acidification on the foraminiferal carbonate flux can be made with confidence only once these complexities have been taken into account. 
To quantify the foraminiferal carbonate flux, further model development should be encouraged, particularly the incorporation of enhanced species diversity, shell calcification processes and empirical relationships between environmental conditions and foraminiferal size. Ideally, future models will also incorporate the physiological response of foraminiferal calcification to multiple environmental drivers.

\subsection{Future challenges}

The challenge remains to observationally evaluate how well Foraminifera models capture changes in abundance in response to environmental change. There is little large-scale observational evidence for historical trends in foraminiferal abundance and diversity over the period of anthropogenic climate change. Large-scale changes in foraminiferal abundance have been observed in continuous plankton records over the last 5 decades in the North Atlantic that are intriguingly similar to our simulations (McQuatters-Gollop et al., 2010), with a large increase in the frequency of plankton occurrence between 40 and $60^{\circ} \mathrm{N}$. However, further analysis of this data set is required before a quantitative assessment can be made. Changes in species composition in response to anthropogenic climate change have been observed in the sediment record of the Santa Barbara Basin (Field et al., 2006). It was shown that historical warming trends were associated with an increase in the abundance of tropical and subtropical species and a decrease in subpolar and polar species (i.e. $N$. pachyderma) over the 20th century.

Ideally, the FORAMCLIM simulations should be tested against present-day time series of planktonic abundance and the key environmental variables such as temperature, phytoplankton concentration and light. For future studies, there are several instrumental records that should become available and provide an invaluable resource to improve our understanding of the environmental controls on the biogeography of Foraminifera, including data collected with (i) plankton tows, (ii) sediment traps (Zaric et al., 2005), (iii) sediment cores and (iv) continuous plankton recorders (CPR).

The plankton tow data used here for the construction of the empirical relationships between physiological growth rates and abundances represent only a subsample of what should become available in the future. More studies of historical trends in the assemblage of planktonic Foraminifera deposited in ocean sediments, such as that of Field et al. (2006), would be invaluable for evaluating the longer-term responses of species assemblages to climate change. However, such studies are restricted to ocean sediment cores from locations with high sedimentation rates and sufficient temporal resolution to determine historical trends. These would not be expected to provide the spatial coverage required for the basin-scale evaluation of global models. CPR records provide long time series of plankton diversity, yet, unfortunately, we found that the routine preservation protocol used to store CPR samples did not preserve Foraminifera well enough to determine relative abundances or shell weights for the construction of historical long-term time series. Only the most robust individuals were preserved, and even their shells were found to be brittle and difficult to speciate. This should be less of a problem for younger samples. Another potential complication with foraminiferal CPR data is that the sample may not represent the mean surface ocean distribution of Foraminifera because (i) the CPR does not resolve different water depths and (ii) the large mesh size (> $200 \mu \mathrm{m})$ means that the smaller fraction of the foraminiferal fauna is not captured in the samples. Nevertheless, by taking the statistics of the CPR sampling protocol into account, it should be possible to use the total abundance of Foraminifera recorded in the original written records for each CPR sample to evaluate the simulated changes in total foraminiferal abundance from the model.

Sedimentary paleorecords on glacial-interglacial timescales may be useful analogues for historical climate change. However, it can be difficult to know which combination of species is driving the observed changes in relative abundance. The differential dissolution of Foraminifera in the sediments further complicates the interpretation of the signals recorded here. Also, we do not have direct measurements of the key environmental drivers of foraminiferal abundance - temperature, light, food availability - back through time and must draw on proxy-based estimates of these quantities, which are plagued by similar uncertainties, and the proxies themselves are often based on Foraminifera.

Improved skill in representing the simulated responses of foraminiferal growth and abundance to environmental change and variability in models will increase our confidence in both future projections of foraminiferal biogeography and the reconstructions of past climates. Subsequent studies should focus on (i) the continued sampling of foraminiferal diversity, abundance and shell size and concomitant biophysical parameters to quantify changes in their distributions in response to environmental perturbations and (ii) evaluating the detectability of large-scale biogeographical shifts driven by climate change given the natural variability in foraminiferal distributions. Given that the distributions of Foraminifera are one of the best known of all the taxa in the pelagic ocean and given the feasibility of monitoring the large-scale changes in Foraminifera, we have confidence that ongoing model-data syntheses should lead to the detection and attribution of anthropogenically driven changes in largescale planktonic foraminiferal distributions.

\section{The Supplement related to this article is available online at doi:10.5194/bg-12-2873-2015-supplement.}


Acknowledgements. This work was supported through the EU FP7 project EPOCA (grant no. 211384). We also thank Ralf Schiebel and Elisabeth Michel for the useful discussions and the two reviewers for offering their time and expertise to review the manuscript.

Edited by: H. Kitazato

\section{References}

Aldridge, D., Beer, C. J., and Purdie, D. A.: Calcification in the planktonic foraminifera Globigerina bulloides linked to phosphate concentrations in surface waters of the North Atlantic Ocean, Biogeosciences, 9, 1725-1739, doi:10.5194/bg-9-17252012, 2012.

Al-Saboui, N., Kucera, M., and Schmidt, D. N.: Vertical niche separation control of diversity and size disparity in planktonic foraminifera. Mar. Micropaleontol., 63, 75-90, 2007.

Anderson, L. A. and Sarmiento, J. L.: Redfield ratios of remineralization determined by nutrient data analysis, Global Biogeochem. Cy., 8, 65-80, 1994.

Aumont, O. and Bopp, L.: Globalizing results from ocean in situ iron fertilization studies, Global Biogeochem. Cy., 20, doi:10.1029/2005GB002591, 2006.

Aumont, O., Maier-Reimer, E., Blain, S., and Monfray, P.: An ecosystem model of the global ocean including $\mathrm{Fe}, \mathrm{Si}, \mathrm{P}$ colimitations, Global Biogeochem. Cy., 17, doi:10.1029/2001GB001745, 2003

Aurahs, R., Grimm, G. W., Hemleben, V., Hemleben, C., and Kucera, M.: Geographical distribution of cryptic genetic types in the planktonic foraminifer Globigerinoides ruber, Molecular Ecol., 18, 1692-1706, 2009.

Barker, S. and Elderfield, H.: Foraminiferal calcification response to glacial-interglacial changes in atmospheric $\mathrm{CO}_{2}$, Science, 297, 833-836, 2002.

Barrows, T. T. and Juggins, S.: Sea-surface temperatures around the Australian margin and Indian ocean during the last glacial maximum, Quaternary Sci. Rev., 24, 1017-1047, 2005.

Bé, A. W. H. and Tolderlund, D. S.: 6. Distribution and ecology of living planktonic foraminifera in surface waters of the Atlantic and Indian oceans, in: Micropaleontology of oceans, London, UK, Cambridge University Press, 1971.

Beer, C. J., Schiebel, R., and Wilson, P. A.: Testing planktic foraminiferal shell weight as a surface water CO32-proxy using plankton net samples, Geology, 38, 103-106, 2010.

Bergami, C., Capotondi, L., Langone, L., Giglio, F., and Ravaioli, M.: Distribution of living planktonic foraminifera in the Ross Sea and the Pacific sector of the Southern Ocean (Antarctica), Mar. Micropaleontol., 73, 37-48, 2009.

Berger, W. H. and Piper, D. J. W.: Planktonic foraminifera - differential settling, dissolution, and redeposition, Limnol. Oceanogr., 17, 275-287, 1972.

Bijma, J., Faber, W. W., and Hemleben, C.: Temperature and salinity limits for growth and survival of some planktonic foraminifers in laboratory cultures, J. Foramin. Res., 20, 95-116, 1990.

Bijma, J., Hemleben, C., Oberhansli, H., and Spindler, M.: The effects of increased water fertility on tropical spinose planktonic foraminifers in laboratory cultures, J. Foramin. Res., 22, 242$256,1992$.
Bijma, J., Spero, H. J., and Lea, D. W.: Reassessing foraminiferal stable isotope geochemistry: Impact of the oceanic carbonate system (experimental results), in: Use of Proxies in Paleoceanography: Example from the South Atlantic, edited by: Fischer, G. and Wefer, G., New York, Springer-Verlag, 489-592, 1999.

Bijma, J., Honisch, B., and Zeebe, R. E.: Impact of the ocean carbonate chemistry on living foraminiferal shell weight: Comment on "Carbonate ion concentration in glacial-age deep waters of the Caribbean Sea" by W. S. Broecker and E. Clark, Geochem. Geophy. Geosy., 3, 1-7, 2002.

Buitenhuis, E. T., Vogt, M., Moriarty, R., Bednaršek, N., Doney, S. C., Leblanc, K., Le Quéré, C., Luo, Y.-W., O’Brien, C., O’Brien, T., Peloquin, J., Schiebel, R., and Swan, C.: MAREDAT: towards a world atlas of MARine Ecosystem DATa, Earth Syst. Sci. Data, 5, 227-239, doi:10.5194/essd-5-227-2013, 2013.

Burrows, M. T., Schoeman, D. S., Buckley, L. B., Moore, P., Poloczanska, E. S., Brander, K. M., Brown, C., Bruno, J. F., Duarte, C. M., Halpern, B. S., Holding, J., Kappel, C. V., Kiessling, W., O’Connor, M. I., Pandolfi, J. M., Parmesan, C., Schwing, F. B., Sydeman, W. J., and Richardson, A. J.: The Pace of Shifting Climate in Marine and Terrestrial Ecosystems, Science, 334, 652-655, 2011.

Comeau, S., Jeffree, R., Teyssie, J. L., and Gattuso, J. P.: Response of the Arctic Pteropod Limacina helicina to Projected Future Environmental Conditions, Plos One, 5, doi:10.1371/journal.pone.0011362, 2010.

De La Rocha, C. L. and Passow, U.: Factors influencing the sinking of POC and the efficiency of the biological carbon pump, DeepSea Res. Pt. II, 54, 639-658, 2007.

de Moel, H., Ganssen, G. M., Peeters, F. J. C., Jung, S. J. A., Kroon, D., Brummer, G. J. A., and Zeebe, R. E.: Planktic foraminiferal shell thinning in the Arabian Sea due to anthropogenic ocean acidification?, Biogeosciences, 6, 1917-1925, doi:10.5194/bg-61917-2009, 2009.

de Vargas, C., Bonzon, M., Rees, N. W., Pawlowski, J., and Zaninetti, L.: A molecular approach to biodiversity and biogeography in the planktonic foraminifer Globigerinella siphonifera (d'Orbigny), Mar. Micropaleontol., 45, 101-116, 2002.

de Villiers, S.: Optimum growth conditions as opposed to calcite saturation as a control on the calcification rate and shell-weight of marine foraminifera, Mar. Biol., 144, 45-49, 2004.

Fabry, V. J., Seibel, B. A., Feely, R. A., and Orr, J. C.: Impacts of ocean acidification on marine fauna and ecosystem processes, Ices J. Mar. Sci., 65, 414-432, 2008.

Fairbanks, R. G. and Wiebe, P. H.: Foraminifera and chlorophyll maximum - vertical-distribution, seasonal succession, and paleoceanographic significance, Science, 209, 1524-1526, 1980.

Fairbanks, R. G., Sverdlove, M., Free, R., Wiebe, P. H., and Be, A. W. H.: Vertical-distribution and isotopic fractionation of living planktonic-foraminifera from the Panama basin, Nature, 298, 841-844, 1982.

Feely, R. A., Sabine, C. L., Lee, K., Berelson, W., Kleypas, J., Fabry, V. J., and Millero, F. J.: Impact of anthropogenic $\mathrm{CO}_{2}$ on the $\mathrm{CaCO}_{3}$ system in the oceans, Science, 305, 362-366, 2004.

Field, D. B.: Variability in vertical distributions of planktonic foraminifera in the California Current: Relationships to vertical ocean structure, Paleoceanography, 19, doi:10.1029/2003pa000970, 2004. 
Field, D. B., Baumgartner, T. R., Charles, C. D., Ferreira-Bartrina, V., and Ohman, M. D.: Planktonic foraminifera of the California Current reflect 20th-century warming, Science, 311, 63-66, 2006.

Follows, M. J., Dutkiewicz, S., Grant, S., and Chisholm, S. W.: Emergent biogeography of microbial communities in a model ocean, Science, 315, 1843-1846, 2007.

Fraile, I., Schulz, M., Mulitza, S., and Kucera, M.: Predicting the global distribution of planktonic foraminifera using a dynamic ecosystem model, Biogeosciences, 5, 891-911, doi:10.5194/bg5-891-2008, 2008.

Gangstø, R., Joos, F., and Gehlen, M.: Sensitivity of pelagic calcification to ocean acidification, Biogeosciences, 8, 433-458, doi:10.5194/bg-8-433-2011, 2011.

Gehlen, M., Bopp, L., Emprin, N., Aumont, O., Heinze, C., and Ragueneau, O.: Reconciling surface ocean productivity, export fluxes and sediment composition in a global biogeochemical ocean model, Biogeosciences, 3, 521-537, doi:10.5194/bg-3521-2006, 2006.

Hayes, A., Kucera, M., Kallel, N., Sbaffi, L., and Rohling, E. J.: Glacial Mediterranean sea surface temperatures based on planktonic foraminiferal assemblages, Quaternary Sci. Rev., 24, 999 1016, 2005.

Hemleben, C., Spindler, M., and Anderson, O. R.: Modern Planktonic Foraminifera, New York, Springer-Verlag, 1989.

Honjo, S.: Fluxes of particles to the interior of the open oceans, in: Particle Flux in the Ocean, edited by: Ittekkot, V., Schafer, P., Honjo, S., and Depetris, P. J., Wiley, New York, 91-154, 1996.

Hourdin, F., Musat, I., Bony, S., Braconnot, P., Codron, F., Dufresne, J. L., Fairhead, L., Filiberti, M. A., Friedlingstein, P., Grandpeix, J. Y., Krinner, G., Levan, P., Li, Z. X., and Lott, F.: The LMDZ4 general circulation model: climate performance and sensitivity to parametrized physics with emphasis on tropical convection, Clim. Dynam., 27, 787-813, 2006.

Jackson, J. B. C. and Sheldon, P. R.: Constancy and change of life in the sea, Philos. T. Roy. Soc. London B, 344, 55-60, 1994.

Kageyama, M., Braconnot, P., Bopp, L., Mariotti, V., Roy, T., Woillez, M.-N., Caubel, A., Foujols, M.-A., Guilyardi, E., Khodri, M., Lloyd, J., Lombard, F., and Marti, O.: Mid-Holocene and last glacial maximum climate simulations with the IPSL model: part II: model-data comparisons, Clim. Dynam., 40, 1-27, 2012.

Keul, N., Langer, G., de Nooijer, L. J., and Bijma, J.: Effect of ocean acidification on the benthic foraminifera Ammonia sp. is caused by a decrease in carbonate ion concentration, Biogeosciences, 10, 6185-6198, doi:10.5194/bg-10-6185-2013, 2013.

Key, R. M., Kozyr, A., Sabine, C. L., Lee, K., Wanninkhof, R., Bullister, J. L., Feely, R. A., Millero, F. J., Mordy, C., and Peng, T. H.: A global ocean carbon climatology: Results from Global Data Analysis Project (GLODAP), Global Biogeochem. Cy., 18, doi:10.1029/2004GB002247, 2004.

Kohfeld, K. E., Fairbanks, R. G., Smith, S. L., and Walsh, I. D.: Neogloboquadrina pachyderma (sinistral coiling) as paleoceanographic tracers in polar oceans: Evidence from northeast water Polynya plankton tows, sediment traps, and surface sediments, Paleoceanography, 11, 679-699, 1996.

Krinner, G., Viovy, N., de Noblet-Ducoudré, N., Ogée, J., Polcher, J., Friedlingstein, P., Ciais, P., Sitch, S., and Prentice, I. C.: A dynamic global vegetation model for studies of the cou- pled atmosphere-biosphere system, Global Biogeochem. Cy., 19, doi:10.1029/2003GB002199, 2005.

Kucera, M., Weinelt, M., Kiefer, T., Pflaumann, U., Hayes, A., Chen, M. T., Mix, A. C., Barrows, T. T., Cortijo, E., Duprat, J., Juggins, S., and Waelbroeck, C.: Compilation of planktic foraminifera census data, modern from the Atlantic Ocean, PANGAEA database, doi:10.1594/PANGAEA.227322, 2004.

Kucera, M., Rosell-Mele, A., Schneider, R., Waelbroeck, C., and Weinelt, M.: Multiproxy approach for the reconstruction of the glacial ocean surface (MARGO), Quaternary Sci. Rev., 24, 813819, 2005.

Kuroyanagi, A. and Kawahata, H.: Vertical distribution of living planktonic foraminifera in the seas around Japan, Mar. Micropaleontol., 53, 173-196, 2004.

Langer, G., Nehrke, G., Probert, I., Ly, J., and Ziveri, P.: Strain-specific responses of Emiliania huxleyi to changing seawater carbonate chemistry, Biogeosciences, 6, 2637-2646, doi:10.5194/bg-6-2637-2009, 2009.

Lombard, F., Labeyrie, L., Michel, E., Spero, H. J., and Lea, D. W.: Modelling the temperature dependent growth rates of planktic foraminifera, Mar. Micropaleontol., 70, 1-7, 2009a.

Lombard, F., Erez, J., Michel, E., and Labeyrie, L.: Temperature effect on respiration and photosynthesis of the symbiontbearing planktonic foraminifera Globigerinoides ruber, Orbulina universa, and Globigerinella siphonifera, Limnol. Oceanogr., 54 210-218, 2009b.

Lombard, F., da Rocha, R. E., Bijma, J., and Gattuso, J.-P.: Effect of carbonate ion concentration and irradiance on calcification in planktonic foraminifera, Biogeosciences, 7, 247-255, doi:10.5194/bg-7-247-2010, 2010.

Lombard, F., Labeyrie, L., Michel, E., Bopp, L., Cortijo, E., Retailleau, S., Howa, H., and Jorissen, F.: Modelling planktic foraminifer growth and distribution using an ecophysiological multi-species approach, Biogeosciences, 8, 853-873, doi:10.5194/bg-8-853-2011, 2011.

Madec, G., Delecluse, P., Imbard, M., and Lévy, M.: OPA 8.1 Ocean General Circulation Model Reference Manual. Notes du Pôle de Modélisation 11, Paris, France, IPSL, 1998.

Manno, C., Morata, N., and Bellerby, R.: Effect of ocean acidification and temperature increase on the planktonic foraminifer Neogloboquadrina pachyderma (sinistral), Polar Biol., 35, 13111319, 2012.

Marland, G. and Andres, T. B. R. J.: Global, regional, and national $\mathrm{CO}_{2}$ emissions. Trends: A Compendium of Data on Global Change, Information Analysis Center, Oak Ridge National Laboratory, U.S. Department of Energy, 2005.

McQuatters-Gollop, A., Burkill, P. H., Beaugrand, G., Johns, D. G., J.-P. G., and Edwards, M.: Atlas of Calcifying Plankton: Results from the North Atlantic Continuous Plankton Recorder survey, Plymouth, UK, Sir Alister Hardy Foundation for Ocean Science, 2010.

Moy, A. D., Howard, W. R., Bray, S. G., and Trull, T. W.:Reduced calcification in modern Southern Ocean planktonic foraminifera, Nature Geosci., 2, 276-280, 2009.

Nakicenovic, N., Alcamo, J., Davis, G., de Vries, B., Fenhann, J., Gaffin, S., Gregory, K., Grübler, A., Yong Jung, T., Kram, T., Lebre La Rovere, E., Michaelis, L., Mori, S., Morita, T., Pepper, W., Pitcher, H., Price, L., Riahi, K., Roehrl, A., Rogner, H., Sankovski, A., Schlesinger, M., Shukla, P., Smith, S., Swart, R., 
van Rooijen, S., Victor, N., and Dadi, Z.: IPCC Special Report on Emission Scenarios, Cambridge University Press, 2000.

Orr, J. C., Fabry, V. J., Aumont, O., Bopp, L., Doney, S. C., Feely, R. A., Gnanadesikan, A., Gruber, N., Ishida, A., Joos, F., Key, R. M., Lindsay, K., Maier-Reimer, E., Matear, R., Monfray, P., Mouchet, A., Najjar, R. G., Plattner, G., Rodgers, K. B., Sabine, C. L., Sarmiento, J. L., Schlitzer, R., Slater, R. D., Totterdell, I. J., Weirig, M., Yamanaka, Y., and Yool, A.: Anthropogenic ocean acidification over the twenty-first century and its impact on calcifying organisms, Nature, 437, 681-686, 2005.

Ortiz, J. D., Mix, A. C., and Collier, R. W.: Environmental-control of living symbiotic and asymbiotic foraminifera of the California current, Paleoceanography, 10, 987-1009, 1995.

Pereira, H. M., Leadley, P. W., Proenca, V., Alkemade, R., Scharlemann, J. P. W., Fernandez-Manjarres, J. F., Araujo, M. B., Balvanera, P., Biggs, R., Cheung, W. W. L., Chini, L., Cooper, H. D., Gilman, E. L., Guenette, S., Hurtt, G. C., Huntington, H. P., Mace, G. M., Oberdorff, T., Revenga, C., Rodrigues, P., Scholes, R. J., Sumaila, U. R., and Walpole, M.: Scenarios for Global Biodiversity in the 21st Century, Science, 330, 1496-1501, 2010.

Retailleau, S., Schiebel, R., and Howa, H.: Population dynamics of living planktic foraminifers in the hemipelagic southeastern Bay of Biscay, Mar. Micropaleontol., 80, 89-100, 2011.

Ridgwell, A., Zondervan, I., Hargreaves, J. C., Bijma, J., and Lenton, T. M.: Assessing the potential long-term increase of oceanic fossil fuel $\mathrm{CO}_{2}$ uptake due to $\mathrm{CO}_{2}$-calcification feedback, Biogeosciences, 4, 481-492, doi:10.5194/bg-4-481-2007, 2007.

Ridgwell, A., Schmidt, D. N., Turley, C., Brownlee, C., Maldonado, M. T., Tortell, P., and Young, J. R.: From laboratory manipulations to Earth system models: scaling calcification impacts of ocean acidification, Biogeosciences, 6, 2611-2623, doi:10.5194/bg-6-2611-2009, 2009.

Riebesell, U., Zondervan, I., Rost, B., Tortell, P. D., Zeebe, R. E., and Morel, F. M. M.: Reduced calcification of marine plankton in response to increased atmospheric $\mathrm{CO}_{2}$, Nature, 407, 364-367, 2000.

Roy, T., Bopp, L., Gehlen, M., Schneider, B., Cadule, P., Frölicher, T. L., Segschneider, J., Tjiputra, J., Heinze, C., and Joos, F.: Regional Impacts of Climate Change and Atmospheric $\mathrm{CO}_{2}$ on Future Ocean Carbon Uptake: A Multimodel Linear Feedback Analysis, J. Climate, 24, 2300-2318, 2011.

Russell, A. D., Honisch, B., Spero, H. J., and Lea, D. W.: Effects of seawater carbonate ion concentration and temperature on shell $\mathrm{U}$, $\mathrm{Mg}$, and $\mathrm{Sr}$ in cultured planktonic foraminifera, Geochim. Cosmochim. Acta, 68, 4347-4361, 2004.

Rutherford, S., D'Hondt, S., and Prell, W.: Environmental controls on the geographic distribution of zooplankton diversity, Nature, 400, 749-753, 1999.

Sarmiento, J. L., Slater, R., Barber, R., Bopp, L., Doney, S. C., Hirst, A. C., Kleypas, J., Matear, R., Mikolajewicz, U., Monfray, P., Soldatov, V., Spall, S. A., and Stouffer, R.: Response of ocean ecosystems to climate warming, Global Biogeochem. Cy., 18, doi:10.1029/2003GB002134, 2004.

Sautter, L. R. and Thunell, R. C.: Planktonic foraminiferal response to upwelling and seasonal hydrographic conditions - sediment trap results from San-Pedro-basin, southern California bight, J. Foramin. Res., 21, 347-363, 1991.
Schiebel, R.: Planktic foraminiferal sedimentation and the marine calcite budget, Global Biogeochem. Cy., 16, 3-1-3-21, doi:10.1029/2001GB001459, 2002.

Schiebel, R. and Movellan, A.: First-order estimate of the planktic foraminifer biomass in the modern ocean, Earth Syst. Sci. Data, 4, 75-89, doi:10.5194/essd-4-75-2012, 2012.

Schiebel, R., Hiller, B., and Hemleben, C.: Impacts of storms on recent planktic foraminiferal test production and $\mathrm{CaCO} 3$ flux in the North Atlantic at 47 degrees N, 20 degrees W (JGOFS), Mar. Micropaleontol., 26, 115-129, 1995.

Schiebel, R., Waniek, J., Bork, M., and Hemleben, C.: Planktic foraminiferal production stimulated by chlorophyll redistribution and entrainment of nutrients, Deep-Sea Res. Pt. I, 48, 721-740, 2001.

Schiebel, R., Zeltner, A., Treppke, U. F., Waniek, J. J., Bollmann, J., Rixen, T., and Hemleben, C.: Distribution of diatoms, coccolithophores and planktic foraminifers along atrophic gradient during SW monsoon in the Arabian Sea, Mar. Micropaleontol., 51, 345-371, 2004.

Schneider, B., Bopp, L., Gehlen, M., Segschneider, J., Frölicher, T. L., Cadule, P., Friedlingstein, P., Doney, S. C., Behrenfeld, M. J., and Joos, F.: Climate-induced interannual variability of marine primary and export production in three global coupled climate carbon cycle models, Biogeosciences, 5, 597-614, doi:10.5194/bg-5-597-2008, 2008.

Seferian, R., Bopp, L., Gehlen, M., Orr, J. C., Ethe, C., Cadule, P., Aumont, O., Salas y Melia, D., Voldoire, A., and Madec, G.: Skill assessment of three earth system models with common marine biogeochemistry, Clim. Dynam., 40, 2549-2573, 2013.

Siegel, D. A. and Deuser, W. G.: Trajectories of sinking particles in the Sargasso Sea: modeling of statistical funnels above deepocean sediment traps, Deep-Sea Res. Pt. I, 44, 1519-1541, 1997.

Spero, H. J.: Do planktic foraminifera accurately record shifts in the carbon isotopic composition of seawater sigma- $\mathrm{CO}_{2}$, Mar. Micropaleontol., 19, 275-285, 1992.

Spero, H. J. and Lea, D. W.: Intraspecific stable-isotope variability in the planktic foraminifera globigerinoides-sacculifer - results from laboratory experiments, Mar. Micropaleontol., 22, 221234, 1993.

Spero, H. J., Bijma, J., Lea, D. W., and Bemis, B. E.: Effect of seawater carbonate concentration on foraminiferal carbon and oxygen isotopes, Nature, 390, 497-500, 1997.

Spindler, M., Hemleben, C., Salomons, J. B., and Smit, L. P.:Feeding-behavior of some planktonic foraminifers in laboratory cultures, J. Foramin. Res., 14, 1-3, 1984.

Steinacher, M., Joos, F., Frölicher, T. L., Bopp, L., Cadule, P., Cocco, V., Doney, S. C., Gehlen, M., Lindsay, K., Moore, J. K., Schneider, B., and Segschneider, J.: Projected 21st century decrease in marine productivity: a multi-model analysis, Biogeosciences, 7, 979-1005, doi:10.5194/bg-7-979-2010, 2010.

von Gyldenfeldt, A. B., Fahrbach, E., Garcia, M. A., and Schroder, M.: Flow variability at the tip of the Antarctic Peninsula, DeepSea Res. Pt. II, 49, 4743-4766, 2002.

Zaric, S., Donner, B., Fischer, G., Mulitza, S., and Wefer, G.: Sensitivity of planktic foraminifera to sea surface temperature and export production as derived from sediment trap data, Mar. Micropaleontol., 55, 75-105, 2005. 
Zondervan, I., Zeebe, R. E., Rost, B., and Riebesell, U.: Decreasing marine biogenic calcification: A negative feedback on rising atmospheric pCO(2), Global Biogeochem. Cy., 15, 507-516, 2001. 